\title{
Condensed tannins in extracts from European medicinal plants and herbal products
}

Article

Accepted Version

Ropiak, H. M., Ramsay, A. and Mueller-Harvey, I. (2016) Condensed tannins in extracts from European medicinal plants and herbal products. Journal of Pharmaceutical and Biomedical Analysis, 121. pp. 225-231. ISSN 0731-7085 doi: https://doi.org/10.1016/j.jpba.2015.12.034 Available at https://centaur.reading.ac.uk/49645/

It is advisable to refer to the publisher's version if you intend to cite from the work. See Guidance on citing.

To link to this article DOI: http://dx.doi.org/10.1016/j.jpba.2015.12.034

Publisher: Elsevier

All outputs in CentAUR are protected by Intellectual Property Rights law, including copyright law. Copyright and IPR is retained by the creators or other copyright holders. Terms and conditions for use of this material are defined in the End User Agreement.

www.reading.ac.uk/centaur

\section{CentAUR}


Central Archive at the University of Reading

Reading's research outputs online 


\section{Condensed tannins in extracts from European medicinal plants and herbal products}

2

3 Honorata M. Ropiak*, Aina Ramsay, Irene Mueller-Harvey*

4

5 Chemistry and Biochemistry Laboratory, School of Agriculture, Policy and Development, 6 University of Reading, P O Box 236, Reading RG6 6AT, UK

7

8 *Corresponding author: h.m.ropiak@ reading.ac.uk, i.mueller-harvey@ reading.ac.uk

polymerization

\section{ABSTRACT}

Medicinal plant materials are not usually analysed for condensed tannins (CT). Thirty commercially available European medicinal plants and herbal products were screened for CT and fourteen CT samples were analysed in detail. This is also the first comprehensive CT analysis of pine buds, walnut leaves and heather flowers and great water dock roots. Acetone/water extracts contained between 3.2 and $25.9 \mathrm{~g} \mathrm{CT} / 100 \mathrm{~g}$ of extract, had CT with mean degrees of polymerisation of 2.9 to 13.3 , procyanidin/prodelphinidin ratios of $1.6 / 98.4$ to $100 / 0$ and cis/trans flavan-3-ol ratios of 17.7/82.3 to 97.3/2.7. The majority of samples contained procyanidins, four contained A-type linkages (blackthorn flowers, heather flowers, bilberry leaves and cowberry leaves) and one sample also had galloylated procyanidins (great water dock roots).

Keywords: Proanthocyanidins, Flavan-3-ols, Molar response factors, Thiolysis, Mean degree of 4 25 


\section{Introduction}

28 Folk medicine in Europe uses plants against a wide range of illnesses [1,2], as food or dietary supplements and as herbal products [3]. The most popular oral intake is via herbal infusion, decoction or as ethanol extracts [2]. Several beneficial actions of medicinal plants have been attributed to tannins $[4,5]$, and their traditional uses include treatments of diarrhoea, heavy metal poisoning [2] or mild peptic ulceration [5]. Condensed tannins (CT, Fig. 1) are also of interest for their antimicrobial, antiviral and antitumour effects; and for their health benefits in cases of cardiovascular, diabetes and inflammatory issues and effects on innate immune responses [6-8]. However, commercially available medicinal plants are not usually analysed for CT and the European Pharmacopeia recommends that all tannins be quantified simply as pyrogallol equivalents [9]; but this provides no accurate information on CT contents or composition. Detailed information on these well-known antioxidants [6] in medicinal plants could prove useful for research into their bioactivities, whether on their own or in combination with other plant compounds $[2,10]$ and may also contribute to the stability of active ingredients. Therefore, we first screened several medicinal plants and herbal products that are widely used in European folk medicine. A subset of extracts from materials with the highest CT contents was then analysed in detail for their flavan-3-ol compositions [11].

\section{Materials and methods}

\subsection{Reagents}

Hydrochloric acid (37\%, AR grade), butan-1-ol, acetic acid glacial (AR grade), acetone (AR grade), acetonitrile (HPLC grade), dichloromethane (LR grade), hexane (GLC, pesticide residue grade) and methanol (HPLC grade) were obtained from ThermoFisher Scientific (Loughborough, UK); benzyl mercaptan (99\%), catechin hydrate ( $\geq 98 \%)$, epicatechin $(90 \%)$, epigallocatechin (95\%), gallocatechin ( $\geq 97 \%$ ), catechin gallate ( $\geq 98 \%)$, epicatechin gallate 
isoquercitrin ( $\geq 90 \%$ ), rutin hydrate ( $\geq 95 \%)$, naringin ( $\geq 95 \%)$, ( \pm )-eriodictyol $(\geq 90 \%)$ from

54 Sigma-Aldrich (Poole, UK); naringenin (97\%) from Alfa Aesar (Lancashire, UK); ( \pm )-taxifolin

55 (98\%) from Apin Chemicals (Abingdon, UK); procyanidin A2 (PC A2, $\geq 99 \%$ ) and naringenin-

7-O-glucoside ( $\geq 99 \%$ ) from Extrasynthese (Genay Cedex, France); afzelechin (96-98\%) from

Plantech UK (Reading, UK) and Sephadex LH-20 from GE Healthcare (Little Chalfont, UK).

\subsection{Plant materials}

60

Pruni spinosae flos, Callunae vulgaris flos, Crataegi inflorescentia, Tiliae inflorescentia,

Betulae folium, Myrtilli folium, Vitis idaeae folium, Ribis nigri folium, Salicis cortex, Lupuli flos,

Hydrolapathi radix (from Poland) and Pini gemmae (typically from Ukraine) were obtained from Flos (Mokrsko, Poland); Juglandis folium (collected in June to August 2012, Poland) from

Kawon (Gostyń, Poland); white clover flowers (Trifolium repens L., collected in April 2012,

Poland) from Zioła z Kurpi (Jednorożec, Poland); (see Table 1). Details of other samples are in

Table A1 and Appendix A.1.1. Plant materials were purchased in 2012/2013 and ground to pass

a $1 \mathrm{~mm}$ sieve (impeller SM1 cutting mill, Retsch, Haan, Germany). Leaves and stalks were removed from blackthorn flowers and only flowers were used.

69

\subsection{Screening plant material for $\mathrm{CT}$ with $\mathrm{HCl} /$ butan-1-ol}

Plant materials were screened for CT presence with $\mathrm{HCl} /$ butan-1-ol [12] (see Appendix A.1.2).

\subsection{Preparation of plant extracts}

Acetone/water was used to prepare the CT extracts [11] (see Appendix A.1.3).

\subsection{CT derivatisation with benzyl mercaptan, HPLC and LC-MS analysis}

77 CT in extracts were derivatised with benzyl mercaptan in triplicate [11]. Samples were analysed within $48 \mathrm{~h}$ by HPLC using gradient 1 [13]. However, heather flowers, bilberry and cowberry 
leaf extracts were analysed with gradient 2 (solvent A: $1 \%$ acetic acid/Milli-Q $\mathrm{H}_{2} \mathrm{O}$; solvent B: acetonitrile) as follows: 0-52 min, 0-36\% B; $52-60 \mathrm{~min}, 36-50 \% \mathrm{~B}$; 60-65 min, 50-100\% B; 6573 min, 100-0\% B; 73-80 min, 0\% B). Flavan-3-ols and their benzyl mercaptan (-BM) adducts were identified [14] and quantified [11] using peak areas at $280 \mathrm{~nm}$ and molar response factors relative to taxifolin: 0.30 for catechin and epicatechin; 0.06 for gallocatechin and epigallocatechin; 0.26 for catechin-BM and epicatechin-BM; 0.06 for gallocatechin-BM and epigallocatechin-BM [14-16]; 0.55 for PC A2, PC A-type trimers and their corresponding -BM adducts [17]; and 1.01 for epicatechin gallate and epicatechin gallate-BM [18] (Appendix A.1.4, A.1.5 and Table A.3). LC-MS was used to confirm the identity of terminal and extension units; MS spectra were recorded in the negative and positive ionisation scan mode and UV spectra at $280 \mathrm{~nm}$ [13] (Table A.3 provides information on [M-H] ${ }^{-}$ions of each detected compound).

\subsection{Quantification of free flavan-3-ols}

Extracts were also assayed for free flavan-3-ol monomers and their 3-O-galloylated derivatives as these interfere with the calculation of CT concentration and composition [19]. Extracts (4 mg) were dissolved in a mixture of methanol $(2.05 \mathrm{ml}), \mathrm{H}_{2} \mathrm{O}(2.5 \mathrm{ml})$ and the internal standard (taxifolin, $0.5 \mathrm{ml} ; 0.05 \mathrm{mg} / \mathrm{ml}$ in methanol), vortexed and centrifuged ( $5 \mathrm{~min}, 3000 \mathrm{rpm}$ ) prior to RP-HPLC or LC-MS analysis. Samples were analysed in duplicate within $24 \mathrm{~h}$.

\subsection{Calculation of CT composition}

The mDP-values of B-type CT and galloylated B-type CT [14, 20], molar percentages of

100 galloylated flavan-3-ols [20], procyanidin/prodelphinidin (PC/PD) ratios and cis/trans flavan-3-

101 ol ratios [14] were calculated as previously reported (see Appendix A.2 for equations to calculate CT composition); however, A-type units were not included in the calculations of cis/trans ratios. Flavan-3-ols in terminal and extension units [21] are reported as relative molar percentages. 
105 The mDP-values of CT that had both B-type and A-type linkages were calculated according to

106 Equation 1, which is derived from a published formula for A-type dimers [7, 22, 23] and refers

107 to molar ratios of terminal and extension flavan-3-ol units:

108

$$
\underset{\text { (CT with B-type }}{\operatorname{mDP}}=\frac{\sum(\mathrm{B}-\text { type } \mathrm{TU})+\sum(\mathrm{B}-\text { type } \mathrm{EU})+\sum(\mathrm{n} \times \mathrm{A}-\text { type } \mathrm{TU})+\sum(\mathrm{n} \times \mathrm{A}-\text { type EU })}{\sum(\mathrm{B}-\text { type } \mathrm{TU})+(\mathrm{A}-\text { type } \mathrm{TU})}
$$

where: TU - terminal unit; EU - extension unit; $n=2$ or 3 and is the degree of polymerisation of

111 terminal or extension units. The percentage of A-type linkages was calculated according to

112 Equation 2 [23] and takes A-type trimers into account:

$\% \mathrm{~A}-$ type linkage $=\frac{\sum(\mathrm{A}-\text { type } \mathrm{TU})+\sum(\mathrm{A}-\text { type } \mathrm{EU})}{\sum(\mathrm{A}-\text { type } \mathrm{TU})+\sum(\mathrm{B}-\text { type } \mathrm{EU})+\sum(\mathrm{n} \times \mathrm{A}-\text { type } \mathrm{EU})}$

\section{Results and discussion}

117 Commercially available medicinal plants, and for that matter also other plants, are rarely analysed for CT contents or compositions, but these compounds are of interest as they have been implicated in numerous health effects [6-8]. Such information could be useful when searching

120 for CT bioactivities or combination effects with other compounds that might be linked to their traditional uses. The main uses in traditional medicine of the samples investigated here are for treating minor urinary tract infections, feverish colds or mild rheumatism (Table 1).

\subsection{Analysis of CT}

125 Initial screening with $\mathrm{HCl} /$ butan-1-ol revealed the presence of $\mathrm{CT}$ in 20 of the 30 plant materials

126 (Table A.2). Samples with $>3 \mathrm{~g} \mathrm{CT} / 100 \mathrm{~g}$ extract were selected for further analysis (see Appendix A.3). 
130 Response factors relative to taxifolin at $280 \mathrm{~nm}$ are widely used for CT analysis after

131 depolymerisation with benzyl mercaptan [14-16, 24]. However, the literature contains several

132 different response factors for flavan-3-ol terminal and extension units $[15,16]$ and these can be

133 affected to some extent by analysis conditions [25]. Some authors have also quantified extension

134 units with response factor ratios against the epicatechin-BM adduct [26] by using the molar

135 response factors reported previously [27]. Others have reported that catechin and epicatechin had

136 the same molar response factors as their corresponding -BM adducts [28] or had relatively

137 similar factors as in the case of epigallocatechin and its -BM adduct [27]. The relative molar

138 responses of flavan-3-ols against taxifolin were, therefore, checked and found to be close to

139 previous reports [14, 15, 24] (see Materials and Methods 2.5).

140 Although mass responses of B-type dimers and trimers relative to epicatechin were similar, i.e.

1410.96 and 1.04 [29], no information exists on the relative mass or molar response factors of A-

142 type dimers and trimers against taxifolin. Two reports stated that the molar absorptivity of the

143 epicatechin dimer (PC A2) was not equal to two times the molar absorptivity of epicatechin at

$144280 \mathrm{~nm}[30,31]$. Indeed, we found a mass response factor of 0.29 and a molar response factor of

1450.55 for the PC A2 dimer against taxifolin, and used the molar response in this study. This is in

146 line with other work, where the relative molar response was twice that of the corrected relative

147 mass response of PC A2 against epicatechin [30]. Finally, the same relative molar response

148 factors were used for the A-type dimer- and trimer-BM adducts in line with a previous report on

149 A-type dimers and their BM adducts [23].

\subsubsection{Characterisation of B-type CT}

152 Overall, CT contents ranged from 3.2 to $20.2 \mathrm{~g} \mathrm{CT} / 100 \mathrm{~g}$ extract, mDP-values from 4.2 to 13.3, PC/PD ratios from 1.6/98.4 to 100/0 and cis/trans flavan-3-ol ratios from 17.7/82.3 to 97.3/2.7

154 (Table 2). Interestingly, most samples contained only B-type PC, i.e. extracts from hawthorn

155 flowers, hop strobiles, Tilia flowers, willow bark and walnut leaves. Only the extract from great 
water dock roots had CT with galloylated flavan-3-ol subunits. White clover flowers had the

157 highest percentage of PD (98.4\%). Cis-flavan-3-ols accounted for $>90 \%$ of the CT subunits in

158 extracts from Tilia flowers, great water dock roots and hawthorn flowers; and blackcurrant

159 leaves had the highest percentage of trans-flavan-3-ols $(82.3 \%)$.

160 This is the first report of the CT flavan-3-ol composition from pine buds and walnut leaf

161 extracts: pine bud CT had an $\mathrm{mDP}$ of 7.8, a PC/PD ratio of 61.5/38.5 and a cis/trans flavan-3-ol

162 ratio of 70.7/29.3 (Table 2); walnut leaf CT had an mDP of 5.1, consisted only of PC with a

163 cis/trans flavan-3-ol ratio of 62.6/37.4. In the following paragraphs, we compare our results

164 from medicinal and herbal products with literature data.

165 White clover flowers contained CT with the highest mDP-value (13.3), the highest PD

166 percentage (98.4\%) and a moderate cis/trans ratio (61.1/38.9; Table 2). This closely resembles

167 previous results where PD percentage was 99\%, cis/trans ratio of $66 / 34$; however, the mDP of

1684.4 was much lower [13]. Epigallocatechin was the main extension unit and gallocatechin was

169 the only terminal unit (Table 3). The blackcurrant leaf extract also contained CT that consisted

170 mostly of PD (95.3\%), had an mDP of 6.0 and a cis/trans ratio of $17.7 / 82.3$ (Table 2). Whilst the

171 mDP-value and PD percentage were similar to previous report (5.4 and 94.2, respectively), the

172 cis/trans ratio differed noticeably (9.1/90.9) [13]. The birch leaf extract had mixed CT with, a

173 PC/PD ratio of 58.9/41.1, an mDP of 4.2 and a cis/trans ratio of 62.9/37.1. These CT contained

174 catechin as the main terminal unit and epicatechin as the main extension unit.

175 The hawthorn flower extract had only PC with an mDP of 4.8 and a cis/trans ratio of 97.3/2.7

176 (Table 2). Epicatechin was found in extension units and both catechin and epicatechin in

177 terminal units (Table 3). Willow bark extract is one of the most studied medicinal plant

178 preparations due to its anti-inflammatory and pain relieving effects [10]. In agreement with

179 others, these CT consisted of pure PC [32] and with a low mDP-value (4.6). Catechin was

180 mainly in the terminal position [32] and the cis/trans ratio was 68.7/31.3. Hop strobiles had pure

181 PC in agreement with the literature [32], although LC-MS analysis detected traces of 
182 gallocatechin and epigallocatechin in extension units (Table 3). These CT had an mDP of 5.1

183 and a cis/trans ratio of 64.0/36.0 (Table 2). The Tilia flower extract also had pure PC with an $\mathrm{mDP}$ of 5.8, which concurs with a report that described PC oligomers up to pentamers [33].

These CT had a very high proportion of cis-flavan-3-ols (90.6\%).

Of particular interest was the great water dock root (Rumex hydrolapathum) extract as it had the highest CT content (25.9 g/100 g extract), a high percentage of cis-flavan-3-ols (94.7\%) and PC that contained 52\% of the flavan-3-ols as gallate esters (Table 2). The chromatographic profile (Fig. A.2-A) was similar to CT from $R$. obtusifolius leaves [24]. $R$. hydrolapathum roots and $R$. obtusifolius leaves contained only PC with similar mDP-values (6.2 vs. 4.3) [24]. However, the extent of galloylation was much higher in $R$. hydrolapathum roots (52 vs. 8\%) [24].

\subsubsection{Characterisation of A-type CT in extracts}

194 A-type linkages were only found amongst PC from blackthorn flowers, cowberry leaves, bilberry leaves, heather flowers and accounted for $25.3,17.1,7.3$, and $6.7 \%$ of the CT, respectively (Table 2; Fig. A.2-B, C, D and E). A-type linkages are usually released by thiolysis as A-type dimers from terminal units or as A-type dimer-BM adducts from extension units [19, 28]. Although one study also reported the release of an A-type trimer from extension units [34].

199 The PC from blackthorn flower extract had a particularly low mDP (2.9) and a moderate cis/trans ratio (67.0/33.0), but had the highest percentage of A-type linkages (25.3\%) which were present in terminal units (Table 2 and 3). Cowberry leaf extract had PC with an mDP of 6.5, a cis/trans ratio of 68.5/31.5 and $17.1 \%$ of the flavan-3-ols had A-type linkages (Table 2). The presence of pure PC agrees with previous report [35]. A-type dimers occurred in terminal units and both A-type dimers were released from extension units (Table 3); somewhat unusually, A-type trimers also came from extension units. Bilberry leaf extract had PC with an mDP of 6.6, a cis/trans ratio of 92.2/7.8 and a low percentage of A-type linkages (7.3\%, Table 2). A-type trimers were detected as terminal units and both A-type dimers and trimers as extension units. 
208 However, no gallocatechin and epigallocatechin were detected in our sample and this suggests

209 that the percentages of PD can vary in bilberry leaves [35].

210 The flavan-3-ol composition of CT from heather flower extract is reported here for the first time.

211 These PC had an mDP of 7.2 and a cis/trans ratio of 87.5/12.5; and 6.7\% of flavan-3-ols were

212 present in A-type linkages. A-type trimers were detected as terminal units and A-type dimers as

213 extension units.

214

215 3.2. Other flavonoids

216 Whilst this work focussed on CT we also provide information on a few flavonoids (rutin,

217 quercetin and quercetin-hexoside) in the Appendix (Table A.3 and Fig. A.1 and A.2). Of

218 particular interest here is an unusual observation in the thiolysed willow bark sample. This

219 solution contained a major peak at 44.6 min that yielded an $[\mathrm{M}-\mathrm{H}]^{-}$ion at $\mathrm{m} / \mathrm{z}$ of 271 (Fig. A.1-I)

220 and a UV/VIS spectrum and retention time that matched authentic naringenin. However, this

221 compound was not present in the original extract, which had contained two distinctive peaks at

22232.4 and 32.9 min that gave rise to $[\mathrm{M}-\mathrm{H}]^{-}$ions at $m / z, 433,[\mathrm{M}+\mathrm{H}]^{+}$ions at $\mathrm{m} / z, 435$ and cleavage

223 products of $m / z 273$ (Table A.3). Both peaks were reduced to two minor peaks after thiolysis

224 (Fig. A.1-J), which probably suggests that the naringenin peak was generated during thiolysis.

225 However, authentic naringenin-7-O-glucoside (with a retention time of $34.5 \mathrm{~min}$ ) was not

226 cleaved during thiolysis. Given that naringenin, naringenin-7-O-glucoside and ( \pm )-naringenin-5-

$227 O$-glucoside (as two peaks) were previously detected in willow bark [10], we propose that,

228 surprisingly, ( \pm -naringenin-5-O-glucoside was degraded under the relatively mild conditions of 229 this thiolysis reaction.

230

231

\section{Conclusions}


232 Condensed tannins were characterised in acetone/water extracts from fourteen widely used

233 medicinal plants and herbal products. Ten samples had pure procyanidins, two had almost pure

234 prodelphinidins, and another two had CT as mixtures of procyanidins and prodelphinidins. Four

235 extracts also contained A-type procyanidins and one extract had CT with 52\% of the flavan-3-ol

236 units as galloylated derivatives. To our knowledge, this is the first detailed analysis of CT in

237 extracts from pine buds, walnut leaves, great water dock roots and heather flowers. Tannins

238 occur in >80 dicotyledonous plant families [36]; however, information on tannin composition is

239 generally hard to find, as their analysis is not trivial [31]. In contrast to food databases [37],

240 European medicinal plants are not generally screened for CT contents or compositions [9]

241 despite the fact that information on CT in medicinal plants would present opportunities for

242 studying their health effects and could add useful information to a medicinal plant database.

243 Such a database could provide a valuable tool for research into CT bioactivities or on their

244 additive or synergistic effects with other compounds. In addition, it could contribute to the

245 standardisation and quality control of herbal products.

\section{Acknowledgements}

248 This study was supported by an EU Marie Curie Initial Training Network (PITN-GA-2011-

249 289377, "LegumePlus"). We thank Ms T.D. Ropiak for help in obtaining plant material Prof

250 E.M. Williamson and Dr P. Lachmann for constructive discussions, Mr R.H. Brown, Mr C.

251 Drake, C. Fryganas, Ms C. Klongsiriwet and Ms P.H. Majid for help in the laboratory.

253 Appendix A. Supplementary data

References 
[1] British Herbal Medicine Association, A guide to traditional herbal medicines. A sourcebook

257 of accepted traditional uses of medicinal plants within Europe, BHMA Publishing Ltd., Dorset, 2582003.

259 [2] A. Gurib-Fakim, Medicinal plants: traditions of yesterday and drugs of tomorrow, Mol.

260 Aspects Med. 27 (2006) 1-93.

261 [3] MedicinesComplete, Herbal Medicines, Pharmaceutical Press, London,

262 https://www.medicinescomplete.com/mc/herbals/current/HBL1000727608.htm (Accessed on 08

263 October 2014).

264 [4] E. Haslam, Natural polyphenols (vegetable tannins) as drugs: possible modes of action, J.

265 Nat. Prod. 59 (1996) 205-215.

266 [5] S. Mills, K. Bone, Principle and Practice of Phytotherapy, Modern Herbal Medicine,

267 Churchill Livingstone, 2000.

268 [6] C. Santos-Buelga, A. Scalbert, Proanthocyanidins and tannin-like compounds - nature,

269 occurrence, dietary intake and effects on nutrition and health, J. Sci. Food Agric. 80 (2000)

$270 \quad 1094-1117$.

271 [7] M. Takeshita, Y. Ishida, E. Akamatsu, Y. Ohmori, M. Sudoh, H. Uto, H. Tsubouchi, H.

272 Kataoka, Proanthocyanidin from blueberry leaves suppresses expression of subgenomic hepatitis

273 C virus RNA, J. Biol. Chem. 284 (2009) 21165-21176.

274 [8] J. Holderness, L. Jackiw, E. Kimmel, H. Kerns, M. Radke, J.F. Hedges, C. Petrie, P.

275 McCurley, P.M. Glee, A. Palecanda, M.A. Jutila, Select plant tannins induce IL-2R $\alpha$ up-

276 regulation and augment cell division in $\gamma \delta$ T cells, J. Immunol. 179 (2007) 6468-6478.

277 [9] British Pharmacopoeia Commission, British Pharmacopoeia, The Stationery Office, London, 2782012.

279 [10] G.A. Bonaterra, E.U. Heinrich, O. Kelber, D. Weiser, J. Metz, R. Kinscherf, Anti-

280 inflammatory effects of the willow bark extract STW 33-I $\left(\right.$ Proaktiv $\left.^{\circledR}\right)$ in LPS-activated human

281 monocytes and differentiated macrophages, Phytomedicine 17 (2010) 1106-1113. 
282 [11] A.R. Williams, H.M. Ropiak, C. Fryganas, O. Desrues, I. Mueller-Harvey, S.M. Thamsborg,

283 Assessment of the anthelmintic activity of medicinal plant extracts and purified condensed

284 tannins against free-living and parasitic stages of Oesophagostomum dentatum, Parasit Vectors 7

$285 \quad(2014) 518$

286 [12] L.J. Porter, L.N. Hrstich, B.G. Chan, The conversion of procyanidins and prodelphinidins to 287 cyanidin and delphinidin, Phytochemistry 25 (1986) 223-230.

288 [13] A.R. Williams, C. Fryganas, A. Ramsay, I. Mueller-Harvey, S.M. Thamsborg, Direct

289 anthelmintic effects of condensed tannins from diverse plant sources against Ascaris suum, PLoS

290 ONE, 9 (2014) e97053. doi:97010.91371/journal.pone.0097053.

291 [14] A. Gea, E. Stringano, R.H. Brown, I. Mueller-Harvey, In situ analysis and structural 292 elucidation of sainfoin (Onobrychis viciifolia) tannins for high-throughput germplasm screening,

293 J. Agric. Food Chem. 59 (2011) 495-503.

294 [15] S. Sivakumaran, A.L. Molan, L.P. Meagher, B. Kolb, L.Y. Foo, G.A. Lane, G.A. Attwood, K. Fraser, M. Tavendale, Variation in antimicrobial action of proanthocyanidins from Dorycnium rectum against rumen bacteria, Phytochemistry 65 (2004) 2485-2497.

297 [16] L.P. Meagher, G. Lane, S. Sivakumaran, M.H. Tavendale, K. Fraser, Characterization of

298 condensed tannins from Lotus species by thiolytic degradation and electrospray mass

299 spectrometry, Anim Feed Sci Technol 117 (2004) 151-163.

300 [17] A.R. Williams, A. Ramsay, T.V.A. Hansen, H.M. Ropiak, H. Mejer, P. Nejsum, I. Mueller-

301 Harvey, S.M. Thamsborg, Anthelmintic activity of trans-cinnamaldehyde and A- and B-type

302 proanthocyanidins derived from cinnamon (Cinnamomum verum), Sci. Rep. (2015) 14791.

303 [18] A. Ramsay, A.R. Williams, S.M. Thamsborg, I. Mueller-Harvey, Galloylated

304 proanthocyanidins from shea (Vitellaria paradoxa) meal have potent anthelmintic activity against Ascaris suum, Phytochemistry (accepted 11 Dec 2015). 
[19] L. Gu, M.A. Kelm, J.F. Hammerstone, G. Beecher, J. Holden, D. Haytowitz, R.L. Prior,

307 Screening of foods containing proanthocyanidins and their structural characterization using LC-

308 MS/MS and thiolytic degradation, J. Agric. Food Chem. 51 (2003) 7513-7521.

309 [20] B. Labarbe, V. Cheynier, F. Brossaud, J.M. Souquet, M. Moutounet, Quantitative

310 fractionation of grape proanthocyanidins according to their degree of polymerization, J. Agric.

311 Food Chem. 47 (1999) 2719-2723.

312 [21] M. Monagas, C. Gómez-Cordovés, B. Bartolomé, O. Laureano, J.M. Ricardo da Silva,

313 Monomeric, Oligomeric, and Polymeric Flavan-3-ol Composition of Wines and Grapes from

314 Vitis vinifera L. Cv. Graciano, Tempranillo, and Cabernet Sauvignon, J. Agric. Food Chem. 51

315 (2003) 6475-6481.

316 [22] E. Le Roux, T. Doco, P. Sarni-Manchado, Y. Lozano, V. Cheynier, A-type

317 proanthocyanidins from pericarp of Litchi chinensis, Phytochemistry 48 (1998) 1251-1258.

318 [23] I. Tarascou, J.-P. Mazauric, E. Meudec, J.-M. Souquet, D. Cunningham, S. Nojeim, V.

319 Cheynier, H. Fulcrand, Characterisation of genuine and derived cranberry proanthocyanidins by

320 LC-ESI-MS, Food Chem. 128 (2011) 802-810.

321 [24] L.P. Meagher, P. Spencer, G.A. Lane, S. Sivakumaran, K. Fraser, What do green tea, grapes 322 seeds, and docks have in common?, Chem. N.Z. 69 (2005) 6-9.

323 [25] H. Wang, G.J. Provan, K. Helliwell, HPLC determination of catechins in tea leaves and tea 324 extracts using relative response factors, Food Chem. 81 (2003) 307-312.

[26] J.K. Hellström, A.R. Törrönen, P.H. Mattila, Proanthocyanidins in common food products of plant origin, J. Agric. Food Chem. 57 (2009) 7899-7906.

327 [27] N. Vivas, M.-F. Nonier, N.V. de Gaulejac, C. Absalon, A. Bertrand, M. Mirabel,

328 Differentiation of proanthocyanidin tannins from seeds, skins and stems of grapes (Vitis vinifera) and heartwood of Quebracho (Schinopsis balansae) by matrix-assisted laser desorption/ionization time-of-flight mass spectrometry and thioacidolysis/liquid 
331 chromatography/electrospray ionization mass spectrometry, Anal. Chim. Acta 513 (2003) 247-

332256.

333 [28] L. Gu, M. Kelm, J.F. Hammerstone, G. Beecher, D. Cunningham, S. Vannozzi, R.L. Prior,

334 Fractionation of polymeric procyanidins from lowbush blueberry and quantification of

335 procyanidins in selected foods with an optimized normal-phase HPLC-MS fluorescent detection

336 method, J. Agric. Food Chem. 50 (2002) 4852-4860.

337 [29] R.L. Prior, L. Gu, Occurrence and biological significance of proanthocyanidins in the

338 American diet, Phytochemistry 66 (2005) 2264-2280.

339 [30] J.L. Koerner, V.L. Hsu, J. Lee, J.A. Kennedy, Determination of proanthocyanidin A2

340 content in phenolic polymer isolates by reversed-phase high-performance liquid

341 chromatography, J. Chromatogr. A 1216 (2009) 1403-1409.

342 [31] W. Hümmer, P. Schreier, Analysis of proanthocyanidins, Mol. Nutr. Food Res. 52 (2008)

$343 \quad 1381-1398$.

344 [32] T. Esatbeyoglu, V. Wray, P. Winterhalter, Dimeric procyanidins: screening for B1 to B8

345 and semisynthetic preparation of B3, B4, B6, and B8 from a polymeric procyanidin fraction of

346 white willow bark (Salix alba), J. Agric. Food Chem. 58 (2010) 7820-7830.

347 [33] A. Karioti, L. Chiarabini, A. Alachkar, M. Fawaz Chehna, F.F. Vincieri, A.R. Bilia, HPLC-

348 DAD and HPLC-ESI-MS analyses of Tiliae flos and its preparations, J. Pharm. Biomed. Anal.

$349100(2014) 205-214$.

350 [34] K. Yokota, H. Kimura, S. Ogawa, T. Akihiro, Analysis of A-type and B-type highly

351 polymeric proanthocyanidins and their biological activities as nutraceuticals, J. Chem. (2013)

352 doi:10.1155/2013/352042.

353 [35] J. Hokkanen, S. Mattila, L. Jaakola, A.M. Pirttilä, A. Tolonen, Identification of phenolic

354 compounds from lingonberry (Vaccinium vitis-idaea L.), bilberry (Vaccinium myrtillus L.) and

355 hybrid bilberry (Vaccinium x intermedium Ruthe L.) leaves, J. Agric. Food Chem. 57 (2009)

$356 \quad 9437-9447$. 
357 [36] E. Haslam, Vegetable tannins - Lessons of a phytochemical lifetime, Phytochemistry 68 358 (2007) 2713-2721.

359 [37] V. Neveu, J. Perez-Jiménez, F. Vos, V. Crespy, L. du Chaffaut, L. Mennen, C. Knox, R.

360 Eisner, J. Cruz, D. Wishart, A. Scalbert, Phenol-Explorer: an online comprehensive database on

361 polyphenol contents in foods, Database 2010 (2010) bap024. doi:10.1093/database/bap024

362 [38] W.C. Evans, Trease and Evans' Pharmacognosy, thirteen ed., Baillière Tindall, London, 3631989.

364 [39] European Medicines Agency,

365 http://www.ema.europa.eu/ema/index.jsp?curl=pages/medicines/landing/herbal_medicines_searc

366 h_landing_page.jsp\&mid= $($ Accessed on 08 October 2014).

367 [40] J.J. Watterson, L.G. Butler, Occurrence of an unusual leucoanthocyanidin and absence of 368 proanthocyanidins in sorghum leaves, J. Agric. Food Chem. 31 (1983) 41-45. 
Table 1 Traditional uses of medicinal plant and herbal product samples investigated in this study.

\begin{tabular}{|c|c|c|c|c|}
\hline $\begin{array}{l}\text { English vernacular } \\
\text { name and part used }\end{array}$ & $\begin{array}{l}\text { Latin name of herbal } \\
\text { substance }\end{array}$ & Botanical name(s) & $\begin{array}{l}\text { Examples of pharmacological } \\
\text { activities/indications } \\
\text { (in single form for traditional uses) }\end{array}$ & $\begin{array}{l}\text { Manufacturers' directions of use } \\
\text { in form of infusion or decoction }\end{array}$ \\
\hline Bilberry leaves (red) & Myrtilli folium $^{\mathrm{b}^{*}, \mathrm{c}}$ & Vaccinium myrtillus L. ${ }^{\mathrm{b}, \mathrm{d}}$ & - & Relaxing and soothing (bath) ${ }^{g}$ \\
\hline Birch leaves & Betulae folium ${ }^{\mathrm{b}, \mathrm{c}}$ & 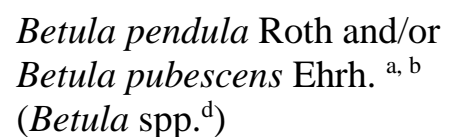 & $\begin{array}{l}\text { Rheumatic complains, urinary illness } \\
\text { (irrigation) [1] }\end{array}$ & Mild urinary tract infections ${ }^{\mathrm{e}}$ \\
\hline Blackcurrant leaves & Ribis nigri folium ${ }^{\mathrm{b}, \mathrm{c}}$ & Ribes nigrum L. ${ }^{\mathrm{a}, \mathrm{b}}$ & $\begin{array}{l}\text { Diuretic, inflammatory disorders } \\
\text { such as rheumatic conditions, } \\
\text { spasmodic cough, colic, diarrhoea } \\
\text { and topically to aid wounds [3] }\end{array}$ & Mild anti-rheumatic ${ }^{\mathrm{e}}$ \\
\hline Blackthorn flowers & Pruni spinosae flos ${ }^{\mathrm{c}}$ & Prunus spinosa L. & - & General health benefits ${ }^{f}$ \\
\hline Cowberry leaves & Vitis idaeae folium ${ }^{\mathrm{c}}$ & Vaccinium vitis-idaea L. & - & $\begin{array}{l}\text { Diuretic for mild urinary tract } \\
\text { inflammation, renal calculus }\end{array}$ \\
\hline Great water dock roots & Hydrolapathi radix ${ }^{\mathrm{c}}$ & Rumex hydrolapathum Huds. & - & Relaxing and soothing (bath) ${ }^{\mathrm{g}}$ \\
\hline Hawthorn flowers & $\begin{array}{l}\text { Crataegi } \\
\text { inflorescentia }^{\mathrm{c}}\end{array}$ & $\begin{array}{l}\text { Crataegus laevigata Poir. }{ }^{\text {a }} \\
\text { (leaves with flowers of }^{\text {Crataegus spp. }}{ }^{\mathrm{d}} \text { ) }\end{array}$ & $\begin{array}{l}\text { Reduction of cardiac performance } \\
\text { (leaves with flowers - more recent } \\
\text { use) [3] }\end{array}$ & $\begin{array}{l}\text { Fatigue, initial mild cardiac } \\
\text { failure where medication is not } \\
\text { required }\end{array}$ \\
\hline Heather flowers & $\begin{array}{l}\text { Callunae vulgaris } \\
\text { flos }^{\mathrm{c}}\end{array}$ & $\begin{array}{l}\text { Calluna vulgaris (L.) Hull. } \\
\text { (leaves with flowers from }^{\text {inflorescence) }}{ }^{\mathrm{d}}\end{array}$ & $\begin{array}{l}\text { Cystitis, urinary infections, } \\
\text { rheumatism (leaves with flowers } \\
\text { from inflorescence) [1] }\end{array}$ & Dietary supplement ${ }^{\mathrm{f}}$ \\
\hline Hop strobiles & Lupuli flos ${ }^{\mathrm{b}, \mathrm{c}}$ & Humulus lupulus L. a, b, d & $\begin{array}{l}\text { Sedative, hypnotic, bactericidal } \\
\text { (topically) [38] insomnia, excitability } \\
\text { [1] neuralgia, priapism, mucous } \\
\text { colitis, crural ulcers, restlessness (due } \\
\text { to nervous tension headache and/or } \\
\text { indigestion) [3] }\end{array}$ & $\begin{array}{l}\text { Insomnia, nervous tension, } \\
\text { calming e }\end{array}$ \\
\hline $\begin{array}{l}\text { Lime tree (Tilia) } \\
\text { flowers }\end{array}$ & $\begin{array}{l}\text { Tiliae inflorescentia } \\
\left.\text { (Tiliae }^{\mathrm{c}} \text { flos }^{\mathrm{b}}\right)\end{array}$ & $\begin{array}{l}\text { Tilia cordata Miller, Tilia } \\
\text { platyphyllos Scop., Tilia } x \\
\left.\text { vulgaris Heyne or their }^{\text {mixtures }}{ }^{\text {a }} \text { Tilia } \text { spp. }^{\mathrm{d}}\right)\end{array}$ & $\begin{array}{l}\text { Sedative, antihypertensive [38], } \\
\text { migraine, feverish cold [1], hysteria, } \\
\text { arteriosclerotic hypertension, arterial } \\
\text { pressure (due to arteriosclerosis and } \\
\text { nervous tension) [3] }\end{array}$ & Feverish cold, diaphoretic ${ }^{\mathrm{e}}$ \\
\hline
\end{tabular}


Pine buds

Walnut leaves

White clover flowers

Willow bark
Pini gemmae ${ }^{\mathrm{c}}$

Juglandis folium $^{\mathrm{b}, \mathrm{c}}$

Trifolii albi flos Salicis cortex ${ }^{\mathrm{b}, \mathrm{c}}$
Pinus spp.

Juglans regia L. $^{\text {b, d }}$

Trifolium repens $\mathrm{L}$.

Salix spp. (various including

S. purpurea L.;

S. daphnoides Vill.;

S. fragilis L.) ${ }^{\mathrm{a}, \mathrm{b}}$
Mild inflammation of skin, excessive perspiration of hand/feet (external use) [1]

Anti-inflammatory, anti-rheumatic

[38] muscular and arthrodial rheumatism with pain and

inflammation, gouty and rheumatoid arthritis, systemic connective tissue disorders with inflammation,

influenza, respiratory catarrh,

ankylosing spondylitis [3]
Illness of upper respiratory tract, mucolytic agent ${ }^{\mathrm{e}}$

Mild inflammation of skin, excessive perspiration of hand/feet (external) ${ }^{\mathrm{e}}$ Relaxing and soothing (bath) ${ }^{g}$ Feverish illness, mild antirheumatic ${ }^{\mathrm{e}}$

Note: ${ }^{\mathrm{a}}-[9],{ }^{\mathrm{b}}-[39],{ }^{\mathrm{b}^{*}}-$ no final opinion [39], ${ }^{\mathrm{c}}-$ as described by manufacturer, ${ }^{\mathrm{d}}-[1]$; sold by manufacturer as either: ${ }^{\mathrm{e}}-$ medicinal product, $^{\mathrm{f}}-$ dietary supplement or ${ }^{\mathrm{g}}$ - herbal product. 
Table 2 Condensed tannin (CT) contents, mean degree of polymerisation (mDP), procyanidin/prodelphinidin (PC/PD) and cis-/trans-flavan-3-ol ratios, percentages of galloylation and A-type linkages in aqueous acetone extracts of medicinal plants or herbal products.

\begin{tabular}{|c|c|c|c|c|c|c|c|c|c|c|c|c|c|c|}
\hline Extract derived from & $(\mathrm{g} / 100 \mathrm{~g}$ & $\begin{array}{l}\text { CT } \\
\text { extract) }\end{array}$ & & DP & & PC & l & PD & & & cis & / trans & & $\%$ galloylation \\
\hline \multirow[t]{2}{*}{ Great water dock roots } & 25.9 & \pm 0.7 & 6.2 & \pm & 0.1 & 100.0 & 1 & 0.0 & \pm & 0.1 & 94.7 & $/ 5.3$ & \pm 0.1 & $52.0 \pm 0.1$ \\
\hline & & & & & & & & & & & & & & $\%$ A-type bond \\
\hline Cowberry leaves & 16.6 & \pm 0.4 & 6.5 & \pm & 0.0 & 100.0 & / & 0.0 & \pm & 0.0 & 68.5 & / 31.5 & \pm 0.1 & $17.1 \pm 0.0$ \\
\hline Heather flowers & 19.3 & \pm 0.4 & 7.2 & \pm & 0.1 & 100.0 & / & 0.0 & \pm & 0.1 & 87.5 & / 12.5 & \pm 0.1 & $6.7 \pm 0.1$ \\
\hline Bilberry leaves & 12.2 & \pm 0.5 & 6.6 & \pm & 0.0 & 100.0 & / & 0.0 & \pm & 0.0 & 92.2 & / 7.8 & \pm 0.0 & $7.3 \pm 0.0$ \\
\hline Blackthorn flowers & 4.0 & \pm 0.2 & 2.9 & \pm & 0.1 & 100.0 & / & 0.0 & \pm & 0.1 & 67.0 & / 33.0 & \pm 0.2 & $25.3 \pm 0.1$ \\
\hline Hawthorn flowers & 11.5 & \pm 0.4 & 4.8 & \pm & 0.0 & 100.0 & 1 & 0.0 & \pm & 0.0 & 97.3 & / 2.7 & \pm 0.0 & \\
\hline Hop strobiles a & 3.2 & \pm 0.1 & 5.1 & \pm & 0.1 & 100.0 & / & 0.0 & \pm & 0.1 & 64.0 & / 36.0 & \pm 0.1 & \\
\hline Tilia flowers & 19.5 & \pm 0.4 & 5.8 & \pm & 0.1 & 100.0 & / & 0.0 & \pm & 0.0 & 90.6 & / 9.4 & \pm 0.0 & \\
\hline White clover flowers ${ }^{a}$ & $13.1^{\mathrm{b}}$ & \pm 0.6 & 13.3 & \pm & 0.1 & 1.6 & / & 98.4 & \pm & 0.1 & 61.1 & / 38.9 & \pm 0.1 & \\
\hline Pine buds & 4.8 & \pm 0.3 & 7.8 & \pm & 0.1 & 61.5 & / & 38.5 & \pm & 0.0 & 70.7 & / 29.3 & \pm 0.0 & \\
\hline Birch leaves ${ }^{a}$ & 4.8 & \pm 0.1 & 4.2 & \pm & 0.1 & 58.9 & 1 & 41.1 & \pm & 0.0 & 62.9 & / 37.1 & \pm 0.0 & \\
\hline Blackcurrant leaves a & $20.2^{b}$ & \pm 0.7 & 6.0 & \pm & 0.1 & 4.7 & 1 & 95.3 & \pm & 0.0 & 17.7 & / 82.3 & \pm 0.0 & \\
\hline Willow bark & 14.6 & \pm 0.7 & 4.6 & \pm & 0.1 & 100.0 & / & 0.0 & \pm & 0.1 & 68.7 & / 31.3 & \pm 0.1 & \\
\hline Walnut leaves & 5.9 & \pm 0.3 & 5.1 & \pm & 0.1 & 100.0 & / & 0.0 & \pm & 0.1 & 62.6 & / 37.4 & \pm 0.1 & \\
\hline
\end{tabular}

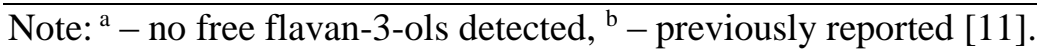


Table 3 Composition of condensed tannins in terms of flavan-3-ols in terminal and extension units (as molar percentages).

\begin{tabular}{|c|c|c|c|c|c|c|c|c|c|c|c|c|c|c|}
\hline \multirow[b]{2}{*}{ Extract derived from } & \multicolumn{14}{|c|}{ Flavan-3-ols (\%) } \\
\hline & $\mathrm{GC}$ & EGC & $\mathrm{C}$ & $\mathrm{EC}$ & $\begin{array}{r}\mathrm{GC} \\
-\mathrm{BM}\end{array}$ & $\begin{array}{l}\mathrm{EGC} \\
-\mathrm{BM}\end{array}$ & $\begin{array}{r}\mathrm{C} \\
-\mathrm{BM}\end{array}$ & $\begin{array}{r}\mathrm{EC} \\
-\mathrm{BM}\end{array}$ & $\mathrm{ECg}$ & $\begin{array}{l}\mathrm{ECg} \\
-\mathrm{BM}\end{array}$ & & & & \\
\hline \multirow{3}{*}{$\begin{array}{r}\text { Great water dock roots } \\
\pm\end{array}$} & 0.0 & 0.0 & 5.3 & 2.4 & 0.0 & 0.0 & 0.0 & 40.3 & 8.5 & 43.5 & & & & \\
\hline & 0.0 & 0.0 & 0.1 & 0.1 & 0.0 & 0.0 & 0.0 & 0.1 & 0.1 & 0.1 & & & & \\
\hline & & & & & & & & & $\begin{array}{r}\mathrm{PC} \\
\text { A-type } \\
\text { trimer } \\
\mathrm{I}\end{array}$ & $\begin{array}{r}\mathrm{PC} \\
\text { A-type } \\
\text { trimer } \\
\mathrm{II} \\
\end{array}$ & $\begin{array}{r}\mathrm{PC} \\
\text { A-type } \\
\text { dimer } \\
\mathrm{I}\end{array}$ & $\begin{array}{r}\mathrm{PC} \\
\text { A-type } \\
\text { dimer } \\
\mathrm{II} \\
\end{array}$ & $\begin{array}{r}\mathrm{PC} \\
\text { A-type } \\
\text { trimer } \\
-\mathrm{BM} \\
\end{array}$ & $\begin{array}{r}\mathrm{PC} \\
\text { A-type } \\
\text { dimer } \\
\text {-BM }\end{array}$ \\
\hline Cowberry leaves & 0.0 & 0.0 & 9.0 & 2.6 & 0.0 & 0.0 & 16.8 & 53.7 & 0.0 & 1.5 & 5.8 & 0.4 & 5.8 & 4.4 \\
\hline \pm & 0.0 & 0.0 & 0.1 & 0.1 & 0.0 & 0.0 & 0.2 & 0.1 & 0.0 & 0.1 & 0.0 & 0.1 & 0.0 & 0.1 \\
\hline \multirow[t]{2}{*}{ Heather flowers } & 0.0 & 0.0 & 8.8 & 4.2 & 0.0 & $*$ & 2.9 & 78.0 & 1.9 & 0.5 & 0.0 & 0.0 & 0.0 & 3.7 \\
\hline & 0.0 & 0.0 & 0.1 & 0.1 & 0.0 & 0.0 & 0.1 & 0.1 & 0.1 & 0.1 & 0.0 & 0.0 & 0.0 & 0.1 \\
\hline \multirow[t]{2}{*}{ Bilberry leaves } & 0.0 & 0.0 & 2.1 & 13.3 & 0.0 & 0.0 & 5.3 & 72.7 & 0.0 & 1.3 & 0.0 & 0.0 & 2.5 & 2.9 \\
\hline & 0.0 & 0.0 & 0.2 & 0.0 & 0.0 & 0.0 & 0.0 & 0.0 & 0.0 & 0.2 & 0.0 & 0.0 & 0.0 & 0.0 \\
\hline Blackthorn flowers & 0.0 & 0.0 & 18.6 & 3.6 & 0.0 & 0.0 & 7.9 & 50.2 & 0.0 & 0.0 & 15.9 & 3.9 & 0.0 & 0.0 \\
\hline \pm & 0.0 & 0.0 & 0.2 & 0.2 & 0.0 & 0.0 & 0.1 & 0.2 & 0.0 & 0.0 & 0.1 & 0.3 & 0.0 & 0.0 \\
\hline \multirow[t]{2}{*}{ Hawthorn flowers } & 0.0 & 0.0 & 2.7 & 18.0 & 0.0 & 0.0 & $*$ & 79.3 & & & & & & \\
\hline & 0.0 & 0.0 & 0.1 & 0.0 & 0.0 & 0.0 & 0.0 & 0.0 & & & & & & \\
\hline \multirow[t]{2}{*}{ Hop strobiles ${ }^{a}$} & 0.0 & 0.0 & 16.6 & 3.0 & $*$ & $*$ & 19.4 & 61.0 & & & & & & \\
\hline & 0.0 & 0.0 & 0.1 & 0.1 & 0.0 & 0.0 & 0.1 & 0.1 & & & & & & \\
\hline \multirow[t]{2}{*}{ Tilia flowers } & 0.0 & 0.0 & 4.2 & 13.1 & 0.0 & 0.0 & 5.2 & 77.5 & & & & & & \\
\hline & 0.0 & 0.0 & 0.1 & 0.1 & 0.0 & 0.0 & 0.1 & 0.0 & & & & & & \\
\hline White clover flowers ${ }^{a}$ & 7.5 & $*$ & 0.0 & 0.0 & 30.8 & 60.1 & 0.0 & 1.0 & & & & & & \\
\hline \pm & 0.1 & 0.0 & 0.0 & 0.0 & 0.1 & 0.1 & 0.0 & 0.1 & & & & & & \\
\hline \multirow[t]{2}{*}{ Pine buds } & $*$ & 0.0 & 12.8 & 0.0 & $*$ & 38.5 & 16.5 & 32.3 & & & & & & \\
\hline & 0.0 & 0.0 & 0.1 & 0.0 & 0.0 & 0.0 & 0.1 & 0.0 & & & & & & \\
\hline
\end{tabular}




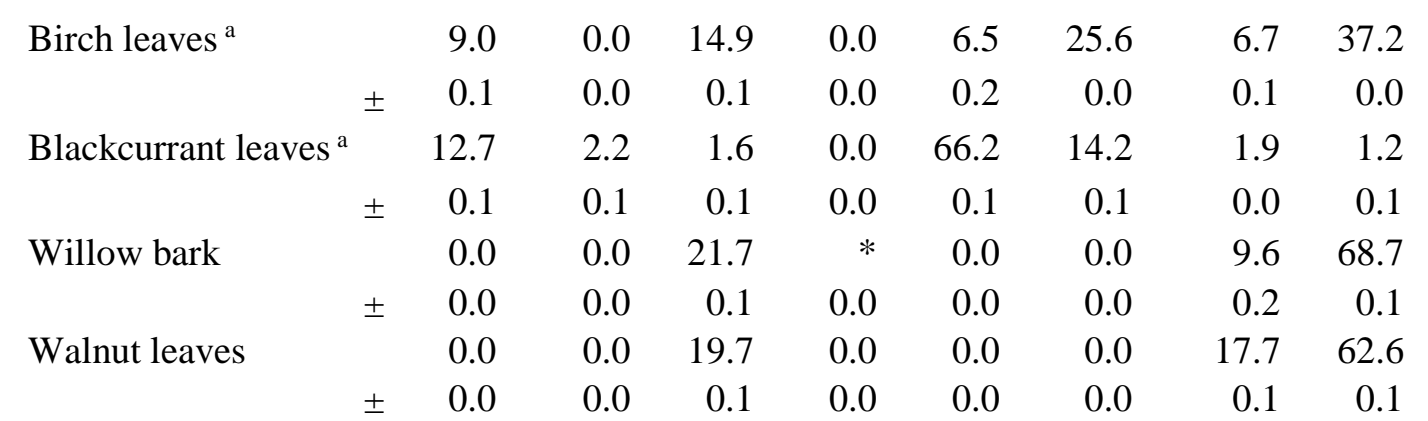

Note: ${ }^{\text {a }}$ - no free flavan-3-ols detected; ${ }^{*}$ - trace amounts detected; GC - gallocatechin, EGC - epigallocatechin, C - catechin, EC - epicatechin, GC-BM gallocatechin benzyl mercaptan adduct, EGC-BM - epigallocatechin benzyl mercaptan adduct, C-BM - catechin benzyl mercaptan adduct, EC-BM epicatechin benzyl mercaptan adduct, ECg - epicatechin gallate, ECg-BM - epicatechin gallate benzyl mercaptan adduct, PC - procyanidins. 


\section{Figure Caption}

Fig. 1. Example of B-type condensed tannins. 
Figure 1

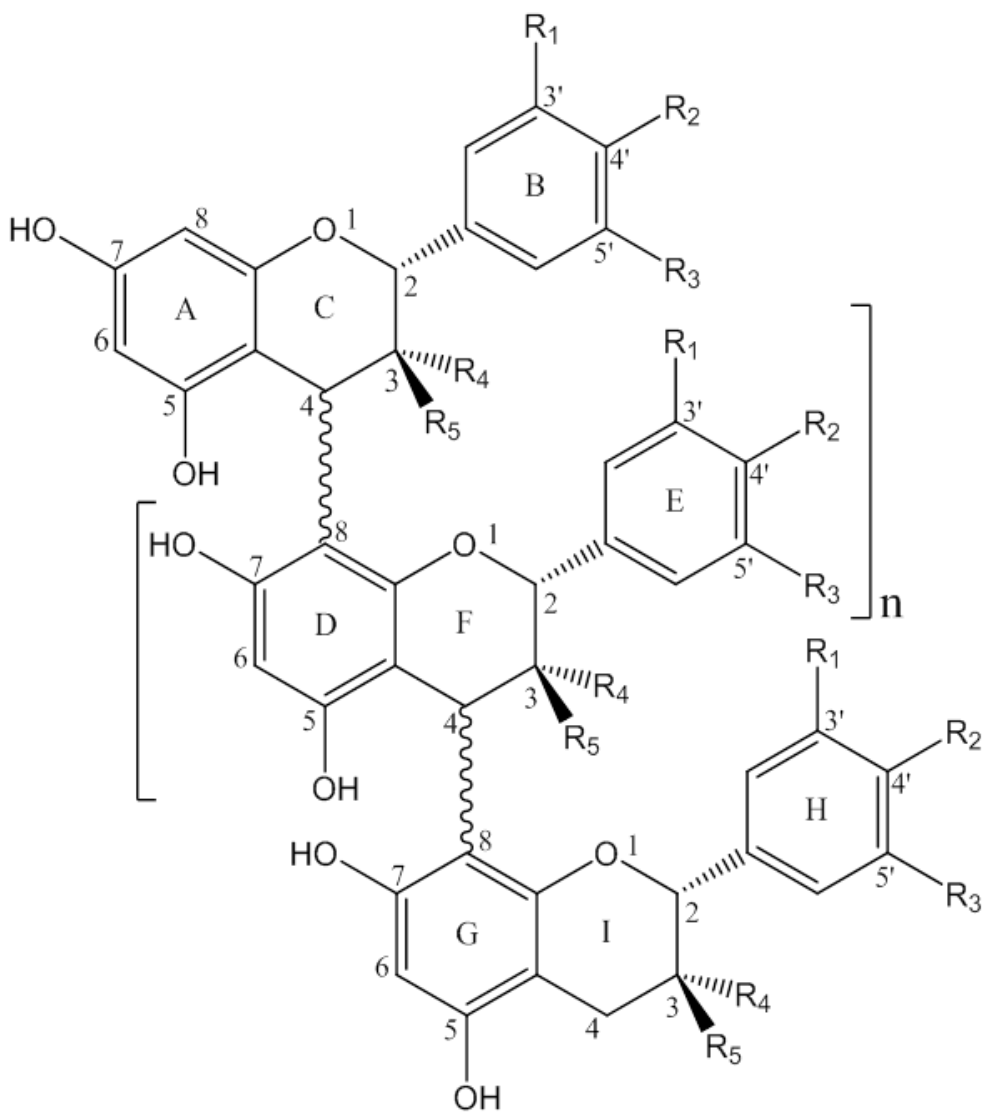

\begin{tabular}{lccccc}
\hline Flavan-3-ol subunits & $\mathrm{R}_{1}$ & $\mathrm{R}_{2}$ & $\mathrm{R}_{3}$ & $\mathrm{R}_{4}$ & $\mathrm{R}_{5}$ \\
\hline Catechin & $\mathrm{OH}$ & $\mathrm{OH}$ & $\mathrm{H}$ & $\mathrm{H}$ & $\mathrm{OH}$ \\
Epicatechin & $\mathrm{OH}$ & $\mathrm{OH}$ & $\mathrm{H}$ & $\mathrm{OH}$ & $\mathrm{H}$ \\
Gallocatechin & $\mathrm{OH}$ & $\mathrm{OH}$ & $\mathrm{OH}$ & $\mathrm{H}$ & $\mathrm{OH}$ \\
Epigallocatechin & $\mathrm{OH}$ & $\mathrm{OH}$ & $\mathrm{OH}$ & $\mathrm{OH}$ & $\mathrm{H}$ \\
\hline
\end{tabular}


Appendix A. 


\section{A.1. Material and methods}

\section{A.1.1 Other plant materials}

Plant material of Robiniae flos, Plantaginis maioris folium, Morus alba L. folium, Salviae folium, Menthae piperitae folium, Crataegi fructus, Pruni spinosae fructus, Sambuci fructus, Urticae radix, Frangulae cortex Calami rhizoma (country of origin: Poland) and Myrtilli fructus (typical country of origin: Poland and Albania) was obtained from Flos (Mokrsko, Poland; GMP and GLP standard compliant); Juniperi fructus (collected in November to December 2012, Poland), Aroniae fructus (collected in August to September 2012, Poland) from Kawon (Gostyń, Poland; ISO 9001:2000 and HACCP compliant); Linum usitatissimum L. (golden linseeds variety, collected in July to August 2011 and/or 2012 from various European countries, de-fatted and milled in Poland) and Chamomillae anthodium (collected in June to July 2011 and/or 2012, Poland) from Herbapol (Lublin, Poland; GMP, BRC Global Standard Food and ECO compliant). Roots and fruits were ground first to pass a $5 \mathrm{~mm}$ and then a $1 \mathrm{~mm}$ sieve. Plant materials were stored in the dark at room temperature.

\section{A.1.2 Screening of plant materials for CT with HCl/butan-1-ol}

Plant materials were first screened for CT presence with $\mathrm{HCl} / \mathrm{butan}-1$-ol in duplicate [12]. $\mathrm{HCl} / \mathrm{butan}-1-\mathrm{ol}(5 \mathrm{ml}, 5: 95 \mathrm{v} / \mathrm{v})$ was added to the plant material $(50 \mathrm{mg})$ in a $10 \mathrm{ml}$ test tube and heated at $95{ }^{\circ} \mathrm{C}$ for $60 \mathrm{~min}$. Corresponding blanks were kept at room temperature to check for the presence of flavan-4-ols or flavan-3,4-diols [40]. Plant materials that gave dark red colour were used for preparing CT extracts (see Table A.2).

\section{A.1.3 Preparation of plant extracts}

Acetone/water was used to prepare the CT extracts [11]. Plant material (20 g) was extracted once with $70 \%$ acetone $/ \mathrm{H}_{2} \mathrm{O}(250 \mathrm{ml})$ by stirring for $60 \mathrm{~min}$ and filtered under vacuum. 
Chlorophyll and lipids were removed with dichloromethane $(125 \mathrm{ml})$. Solvents were removed on a rotary evaporator at $35^{\circ} \mathrm{C}$ and the aqueous phase was centrifuged for 3 min at $4500 \mathrm{rpm}$ (Jouan CR3i Multifunction Centrifuge, Thermo Electron Corporation, Basingstoke, UK). Extracts were freeze-dried and stored at $-20{ }^{\circ} \mathrm{C}$ (see Table A. 2 for extract yields). Deionised water was purified in an Option 3 water purifier (ELGA Process Water, Marlow, UK).

\section{A.1.4 Standards}

Standards were injected in methanol for HPLC analysis: (+)-catechin hydrate, (-)-epicatechin, (-)-gallocatechin and (-)-epigallocatechin and ( \pm )-taxifolin at $0.017 \mathrm{mg} / \mathrm{ml} ;(-)$-catechin gallate, (-)-epicatechin gallate, (-)-epigallocatechin gallate, (-)-gallocatechin gallate, PC A2 $(+)$-afzelechin and $( \pm)$-taxifolin at $0.013 \mathrm{mg} / \mathrm{ml} ;( \pm)$-eriodictyol, isoquercitrin, naringenin, naringin, naringenin-7-O-glucoside, quercetin and rutin at $0.1 \mathrm{mg} / \mathrm{ml}$. Flavonoid standards were injected in methanol/water (80:20 v/v) for LC-MS analysis. Ultrapure water was purified in a Milli-Q Plus system (Millipore, Watford, UK).

Catechin hydrate, epicatechin, gallocatechin and epigallocatechin; catechin gallate, epicatechin gallate, epigallocatechin gallate, gallocatechin gallate, PC A2 and taxifolin were injected at above concentrations for molar response factor evaluation against taxifolin individually or in mixtures Corresponding -BM adducts of these compounds were assumed to have the same molar response factor. PC A-type trimers and their-BM adducts were assumed to have the same molar response factor as PC A2. See Materials and Methods 2.5 and Result and Discussion 3.1.1.

\section{A.1.5. CT quantification}

Due to interfering peaks, quantification was done with taxifolin as an external standard [11], which was prepared as thiolysis blank. Taxifolin was dissolved in the 'thiolysis' reagent, 
which was identical to the thiolysis solution used for samples, but it did not contain the sample and benzyl mercaptan was replaced by methanol.

\section{A.2 Calculations of CT composition}

The following equations were used for the calculation of:

a) mDP-values of B-type CT and galloylated B-type CT [14, 20]:

$$
\mathrm{mDP}=\frac{\sum \mathrm{TU}(\mathrm{mol})+\sum \mathrm{EU}(\mathrm{mol})}{\sum \mathrm{TU}(\mathrm{mol})}
$$

Equation A.2.1

where: TU - terminal flavan-3-ol units; EU - extension flavan-3-ol units;

b) molar percentages of galloylated flavan-3-ols [20] (i.e. \% galloylation):

$$
\% \text { galloylation }=\frac{\sum \text { galloylated } \mathrm{TU}+\sum \text { galloylated } \mathrm{EU}}{\sum \text { all types } \mathrm{TU}+\sum \text { all types } \mathrm{EU}} \times 100
$$

Equation A.2.2

c) procyanidin/prodelphinidin $(\mathrm{PC} / \mathrm{PD})$ ratios $[14]$ :

$$
\mathrm{PC} / \mathrm{PD}=\frac{\left(\sum \mathrm{C} \text { units }+\sum \mathrm{EC} \text { units }\right) \times 100}{\sum \text { all units }} / \frac{\left(\sum \mathrm{GC} \text { units }+\sum \mathrm{EGC} \text { units }\right) \times 100}{\sum \text { all units }}
$$

Equation A.2.3

where: $\mathrm{C}$ - catechin, EC - epicatechin, GC - gallocatechin, EGC - epigallocatechin, all units

$-\mathrm{TU}+\mathrm{EU}$

d) cis/trans flavan-3-ol ratios [14], where A-type units were not included:

$$
\text { cis } / \text { trans }=\frac{\left(\sum \mathrm{EC} \text { units }+\sum \mathrm{EGC} \text { units }\right) \times 100}{\sum \text { all units }} / \frac{\left(\sum \mathrm{C} \text { units }+\sum \mathrm{GC} \text { units }\right) \times 100}{\sum \text { all units }}
$$

Equation A.2.4. 


\section{A.3. Analysis of CT}

Extract yields ranged from 9 to $70 \mathrm{~g} / 100 \mathrm{~g}$ plant dry weight (Table A.2); however, fruit sample extracts had particularly low contents ( $<3 \mathrm{~g} \mathrm{CT} / 100 \mathrm{~g}$ extract, data not shown). No free flavan-3-ols were detected in hawthorn and white clover flowers, hop strobiles, birch and blackcurrant leaves (CT data without correction for free flavan-3-ol monomers are reported for comparison purposes and resulted in minor differences; Table 2 and 3 vs. Table A.5 and A.6). 
Table A.1 List of other medicinal plants and herbal products screened for condensed tannins.

\begin{tabular}{|c|c|c|}
\hline $\begin{array}{l}\text { Example of English } \\
\text { vernacular name and part } \\
\text { of plant used }\end{array}$ & Latin name of herbal substance & Botanical name of plant(s) \\
\hline Bilberry fruits & Myrtilli fructus $^{\mathrm{b}, \mathrm{c}}$ & Vaccinium myrtillus L. ${ }^{\mathrm{a}, \mathrm{b}, \mathrm{d}}$ \\
\hline Black locust flowers & Robiniae flos $^{\mathrm{c}}$ & Robinia pseudoacacia $\mathrm{L}$. \\
\hline Blackthorn fruits & Pruni spinosae fructus ${ }^{\mathrm{c}}$ & Prunus spinosa $\mathrm{L}$. \\
\hline Broadleaf plantain leaves & Plantaginis maioris folium $^{\mathrm{c}}$ & Plantago maior L. \\
\hline Calamus rhizome & Calami rhizoma $^{\mathrm{c}}$ & Acorus calamus $\mathrm{L}$. \\
\hline Chamomile flowers & Chamomillae anthodium $^{\mathrm{c}}$ & Matricaria chamomilla $\mathrm{L}$. \\
\hline Chokeberries fruits & Aroniae fructus ${ }^{\mathrm{c}}$ & Aronia Medik. \\
\hline Elderberry fruits & Sambuci fructus ${ }^{\mathrm{b}^{*}, \mathrm{c}}$ & Sambucus nigra $\mathrm{L}^{\mathrm{b}^{*}}$ \\
\hline Frangula bark & Frangulae cortex ${ }^{\mathrm{b}, \mathrm{c}}$ & Rhamnus frangula L. $^{\mathrm{a}, \mathrm{b}, \mathrm{d}}$ (Frangula alnus Miller) ${ }^{\mathrm{a}}$ \\
\hline Hawthorn fruits & Crataegi fructus $^{\mathrm{c}}$ & $\begin{array}{l}\text { Crataegus monogyna Jacq. (Lindm.); } \\
\text { Crataegus laevigata (Poir.) D.C. or other European }{ }^{\text {a }} \\
\text { Carataegus spp. }{ }^{\text {a d }}\end{array}$ \\
\hline Juniper fruits/berry & $\begin{array}{l}\text { Juniperifructus }{ }^{\mathrm{c}} \text { (Juniperi } \\
\text { pseudo-fructus }^{\mathrm{b}} \text { ) }\end{array}$ & Juniperus communis $\mathrm{L} .{ }^{\mathrm{a}} \mathrm{b}$ \\
\hline Linseed seeds & Lini semen ${ }^{\mathrm{b}}$ & Linum usitatissimum $\mathrm{L}^{\mathrm{a}, \mathrm{b}, \mathrm{d}}$ \\
\hline Nettle roots & Urticae radix ${ }^{\mathrm{b}, \mathrm{c}}$ & Urtica dioica L. ${ }^{\mathrm{d}}$; Urtica urens L. ${ }^{\mathrm{b}}$ \\
\hline Peppermint leaves & Menthae piperitae folium ${ }^{\mathrm{b}, \mathrm{c}}$ & Mentha x piperita $\mathrm{L} . \mathrm{a}, \mathrm{b}, \mathrm{d}$ \\
\hline Sage leaves & $\begin{array}{l}\text { Salviae folium }{ }^{\mathrm{c}} \\
\text { (Salviae officinalis folium }^{\mathrm{b}} \text { ) }\end{array}$ & Salvia officinalis L. ${ }^{\mathrm{a}, \mathrm{b}, \mathrm{d}}$ \\
\hline White mulberry leaves & Morus alba L. folium ${ }^{\mathrm{c}}$ & Morus alba L. \\
\hline
\end{tabular}

Note: ${ }^{\mathrm{a}}-[9],{ }^{\mathrm{b}}-[39],{ }^{\mathrm{b}}-$ no final opinion [39], ${ }^{\mathrm{c}}-$ as described by manufacturer, ${ }^{\mathrm{d}}-[1]$. 
Table A.2 Results of HCl/butanol screening of plant materials and yields ( $\mathrm{g}$ extract/100 g dry weight of plant) of extracts.

\begin{tabular}{|c|c|c|c|c|c|c|c|}
\hline \multirow{2}{*}{ Plant material } & \multicolumn{2}{|c|}{$\mathrm{HCl} /$ butanol } & \multirow{2}{*}{$\begin{array}{r}\text { Yield } \\
(\%)\end{array}$} & \multirow{2}{*}{ Plant material } & \multicolumn{2}{|c|}{$\mathrm{HCl} /$ butanol } & \multirow{2}{*}{$\begin{array}{r}\text { Yield } \\
(\%)\end{array}$} \\
\hline & sample & control & & & sample & control & \\
\hline Great water dock roots & + & - & 26.5 & Blackthorn fruits & + & - & 29.0 \\
\hline Blackthorn flowers & + & - & 24.5 & Bilberry fruits & + & + & 63.0 \\
\hline Hawthorn flowers & + & - & 23.5 & Heather flowers & + & + & 9.0 \\
\hline Willow bark & + & - & 20.5 & Chokeberry fruits & + & + & 46.0 \\
\hline Hop strobiles & + & - & 18.0 & Hawthorn fruits & $+/-$ & - & 65.0 \\
\hline Tilia flowers & + & - & 21.5 & Juniper fruits/berry & - & - & \\
\hline White clover flowers & + & - & 17.0 & Black locust flowers & - & - & \\
\hline Pine buds & + & - & 15.0 & Frangula bark & - & - & \\
\hline Walnut leaves & + & - & 19.0 & Broadleaf plantain leaves & - & - & \\
\hline Bilberry leaves & + & - & 9.5 & Linseed seeds & - & - & \\
\hline Birch leaves & + & - & 24.0 & Sage leaves & - & - & \\
\hline Blackcurrant leaves & + & - & 17.5 & Chamomile flowers & - & - & \\
\hline Cowberry leaves & + & - & 36.0 & Peppermint leaves & - & - & \\
\hline Elderberry fruits & + & - & 44.0 & White mulberry leaves & - & - & \\
\hline Calamus rhizome & + & - & 70.0 & Nettle roots & - & - & \\
\hline
\end{tabular}

Legend: + positive (colour change to red), - negative (no colour change to red). 
Table A.3. Typical HPLC retention times and $\mathrm{m} / \mathrm{z}$ values of flavan-3-ols and selected flavonoids.

\begin{tabular}{|c|c|c|c|c|c|}
\hline \multirow{3}{*}{ No } & \multirow{3}{*}{ Compound } & \multirow{2}{*}{\multicolumn{2}{|c|}{$\begin{array}{l}\text { Retention times } \\
\quad(\min )\end{array}$}} & \multicolumn{2}{|r|}{$m / z$} \\
\hline & & & & \multirow{2}{*}{$\begin{array}{c}\text { Molecular } \\
\text { ion } \\
{[\mathrm{M}-\mathrm{H}]^{-}}\end{array}$} & \multirow{2}{*}{$\begin{array}{l}\text { Typical other } \\
\text { fragments }\end{array}$} \\
\hline & & gradient 1 & gradient 2 & & \\
\hline 1 & Gallocatechin & 20.9 & 19.4 & 305 & 340 \\
\hline 2 & Epigallocatechin & 24.5 & 25.2 & 305 & 340 \\
\hline 3 & Catechin & 26.2 & 26.8 & 289 & 325 \\
\hline 4 & Epicatechin & 28.6 & 31.1 & 289 & 325 \\
\hline 5 & Taxifolin & 34.2 & 38.8 & 303 & \\
\hline 6 & 3,4-trans-gallocatechin-BM & 40.6 & 50.7 & 427 & 303 \\
\hline 7 & 3,4-cis-gallocatechin-BM & 40.9 & 51.8 & 427 & 303 \\
\hline 8 & 3,4-trans-epigallocatechin-BM & 41.3 & 53.8 & 427 & 303 \\
\hline 9 & 3,4-trans-catechin-BM & 43.4 & 57.6 & 411 & 447,287 \\
\hline 10 & 3,4-cis-catechin-BM & 43.9 & 58.2 & 411 & 447,287 \\
\hline 11 & 3,4-trans-epicatechin-BM & 44.4 & 58.8 & 411 & 447,287 \\
\hline 12 & $\begin{array}{l}\text { Benzyl mercaptan and } \\
\text { unidentified compounds }\end{array}$ & 48.5 & 47.8 & - & - \\
\hline 13 & Epicatechin gallate & 33.2 & 39.6 & 441 & 477 \\
\hline 14 & Epicatechin-BM gallate & 43.2 and 45.3 & 61.5 and 62.8 & 563 & 599 \\
\hline 15 & PC A-type trimer & 28.2 and 31.5 & 29.1 and 32.9 & 863 & $497,325,289,141$ \\
\hline 16 & PC A-type dimer & 31.7 and 33.2 & 37.5 and 40.1 & 575 & $615,633,594,319,275,141$ \\
\hline 17 & PC A-type trimer-BM & 42.2 & 56.1 & 986 & $862,510,430,301,141,113$ \\
\hline 18 & PC A-type dimer-BM & 45.3 & 63.1 & 697 & $733,573,437,141,113$ \\
\hline $\mathrm{a}$ & Rutin & 31.7 & 38.5 & 609 & 321 \\
\hline $\mathrm{b}$ & Quercetin-hexoside a, b & 32.9 & 40.1 & 463 & \\
\hline $\mathrm{c}$ & Quercetin $^{\text {a }}$ & 39.6 & 51.9 & 301 & \\
\hline $\mathrm{d}$ & $\begin{array}{l}\text { Possibly } \\
\text { naringenin- } O \text {-hexoside }\end{array}$ & 32.3 and 32.9 & 38.4 and 39.4 & 433 & 593 \\
\hline
\end{tabular}


Note: -BM - benzyl mercaptan adduct, $\mathrm{PC}$ - procyanidins; previously reported: ${ }^{\text {- }}$ - quercetin-3-O-glucoside, quercetin-3-O- $\beta$-galactoside and quercetin were detected in bilberry leaves [35]; ${ }^{\mathrm{b}}$ - quercetin-3-O-glucoside in Tilia flowers [33]; ${ }^{\mathrm{c}}$ - in line with [10]. 
Table A.4 Data of B-type condensed tannins and galloylated procyanidins in extracts that were not corrected for free flavan-3-ols.*

\begin{tabular}{|c|c|c|c|c|c|c|c|c|c|c|c|c|c|}
\hline \multirow{2}{*}{$\begin{array}{l}\text { Extract derived from } \\
\text { Great water dock roots }\end{array}$} & \multicolumn{2}{|c|}{ CT (g/100 g) } & \multicolumn{2}{|c|}{$\mathrm{mDP}$} & \multirow{3}{*}{$\begin{array}{r}\text { PC } \\
100.0\end{array}$} & \multirow[t]{3}{*}{ / } & \multicolumn{2}{|l|}{ PD } & cis & \multicolumn{3}{|c|}{$/$ trans } & $\%$ galloylation \\
\hline & 27.3 & \pm 0.7 & 4.9 & \pm 0.1 & & & 0.0 & \pm 0.1 & 92.1 & 1 & 7.9 & \pm 0.1 & $51.5 \pm 0.1$ \\
\hline & & & & & & & & & & & & & $\%$ A-type bond \\
\hline Cowberry leaves & 17.9 & \pm 0.4 & 4.5 & \pm 0.0 & 100.0 & I & 0.0 & \pm 0.0 & 60.7 & / & 39.3 & \pm 0.1 & $17.1 \pm 0.0$ \\
\hline Heather flowers & 19.5 & \pm 0.4 & 6.8 & \pm 0.1 & 100.0 & 7 & 0.0 & \pm 0.1 & 86.6 & / & 13.4 & \pm 0.1 & $6.7 \pm 0.1$ \\
\hline Bilberry leaves & 12.4 & \pm 0.5 & 6.1 & \pm 0.0 & 100.0 & 1 & 0.0 & \pm 0.0 & 92.3 & / & 7.7 & \pm 0.0 & $7.3 \pm 0.0$ \\
\hline Blackthorn flowers & 4.3 & \pm 0.2 & 2.5 & \pm 0.1 & 100.0 & 1 & 0.0 & \pm 0.1 & 62.9 & / & 37.1 & \pm 0.1 & $25.3 \pm 0.1$ \\
\hline Hawthorn flowers & 11.9 & \pm 0.4 & 4.2 & \pm 0.0 & 100.0 & / & 0.0 & \pm 0.0 & 97.4 & / & 2.6 & \pm 0.0 & \\
\hline Tilia flowers & $21.0^{\mathrm{a}}$ & \pm 0.4 & 5.1 & \pm 0.0 & 100.0 & / & 0.0 & \pm 0.0 & 90.8 & / & 9.2 & \pm 0.0 & \\
\hline Pine buds & 4.8 & \pm 0.3 & 7.0 & \pm 0.1 & 62.2 & I & 37.9 & \pm 0.0 & 69.6 & I & 30.4 & \pm 0.0 & \\
\hline Willow bark & 15.4 & \pm 0.7 & 3.8 & \pm 0.1 & 100.0 & I & 0.0 & \pm 0.1 & 64.8 & I & 35.2 & \pm 0.1 & \\
\hline Walnut leaves & 6.2 & \pm 0.3 & 4.2 & \pm 0.1 & 100.0 & I & 0.0 & \pm 0.1 & 59.5 & I & 40.5 & \pm 0.1 & \\
\hline
\end{tabular}

Note: * - for comparison purposes only, CT - condensed tannin, mDP - mean degree of polymerisation, PC/PD - procyanidin/prodelphinidin ratios, cis/trans - cis-/trans-flavan-3-ol ratios, ${ }^{\mathrm{a}}$ - previously reported [11]. 
Table A.5 Composition of flavan-3-ol in extracts as molar percentages that were not corrected for free flavan-3-ols. ${ }^{\text {a }}$

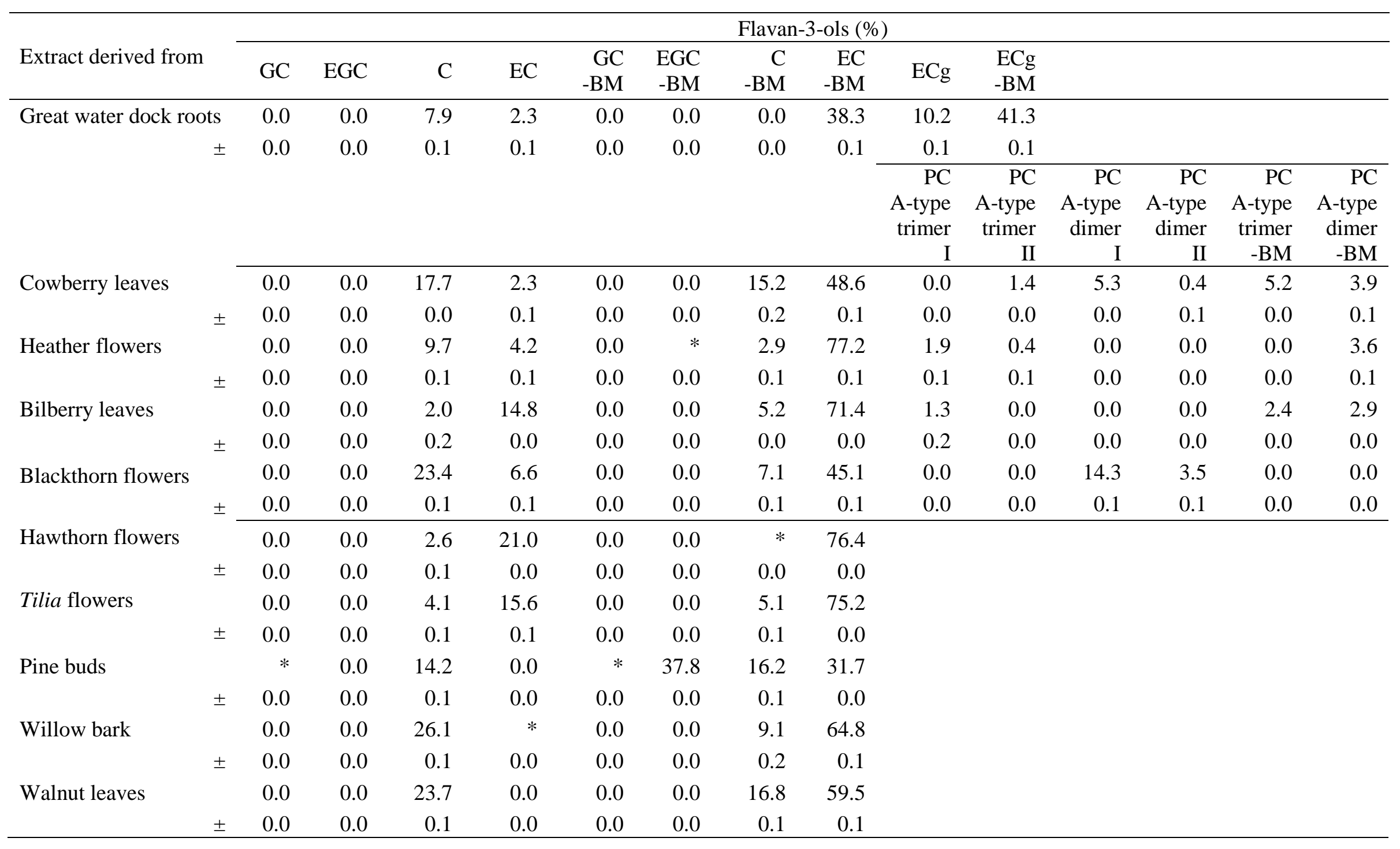


Note: ${ }^{\text {a }}$ - for comparison purposes only, * - trace amounts detected; GC - gallocatechin, EGC - epigallocatechin, C - catechin, EC - epicatechin, GC-BM gallocatechin benzyl mercaptan adduct, EGC-BM - epigallocatechin benzyl mercaptan adduct, C-BM - catechin benzyl mercaptan adduct, EC-BM -

epicatechin benzyl mercaptan adduct, ECg - epicatechin gallate, ECg-BM - epicatechin gallate benzyl mercaptan adduct, PC - procyanidins. 


\section{Figure Captions}

Fig. A.1. Examples of RP-HPLC chromatograms after thiolysis of extracts: A - hawthorn flowers, B - Tilia flowers, C - hop strobiles, D - white clover flowers, E - pine buds, F birch leaves, $\mathrm{G}$ - blackcurrant leaves, $\mathrm{H}$ - walnut leaves, I - willow bark, J - willow bark (not thiolysed, shown for comparison); where: 1 - gallocatechin, 2 - epigallocatechin, 3 catechin, 4 - epicatechin, 5 - taxifolin (internal standard), 6 - gallocatechin-BM (trans), 7 gallocatechin-BM (cis), 8 - epigallocatechin-BM, 9 - catechin-BM (trans), 10 - catechin-BM (cis), 11 - epicatechin-BM, 12 - benzyl mercaptan and unidentified compounds; $\mathrm{a}$ - rutin, bquercetin- $O$-hexoside, c - quercetin, $\mathrm{d}$ - possibly naringenin- $O$-hexoside.

Fig. A.2. Examples of RP-HPLC chromatograms after thiolysis of extracts: A - great water dock roots, $\mathrm{B}$ - cowberry leaves, $\mathrm{C}$ - heather flowers, D - bilberry leaves, $\mathrm{E}$ - blackthorn flowers; where: 1 - gallocatechin, 2 - epigallocatechin, 3 - catechin, 4 - epicatechin, 5 taxifolin (internal standard), 6 - gallocatechin-BM (trans), 7 - gallocatechin-BM (cis), 8 epigallocatechin-BM, 9 - catechin-BM (trans), 10 - catechin-BM (cis), 11 - epicatechin-BM, 12 - benzyl mercaptan and unidentified compounds, 13 - epicatechin gallate, 14 epicatechin-BM gallate, 15 - procyanidin A-type trimer, 16 - procyanidin A-type dimer, 17 procyanidin A-type trimer-BM, 18 - procyanidin A-type dimer-BM; a - rutin, b - quercetin$O$-hexoside, c-quercetin. 
Figure A.1

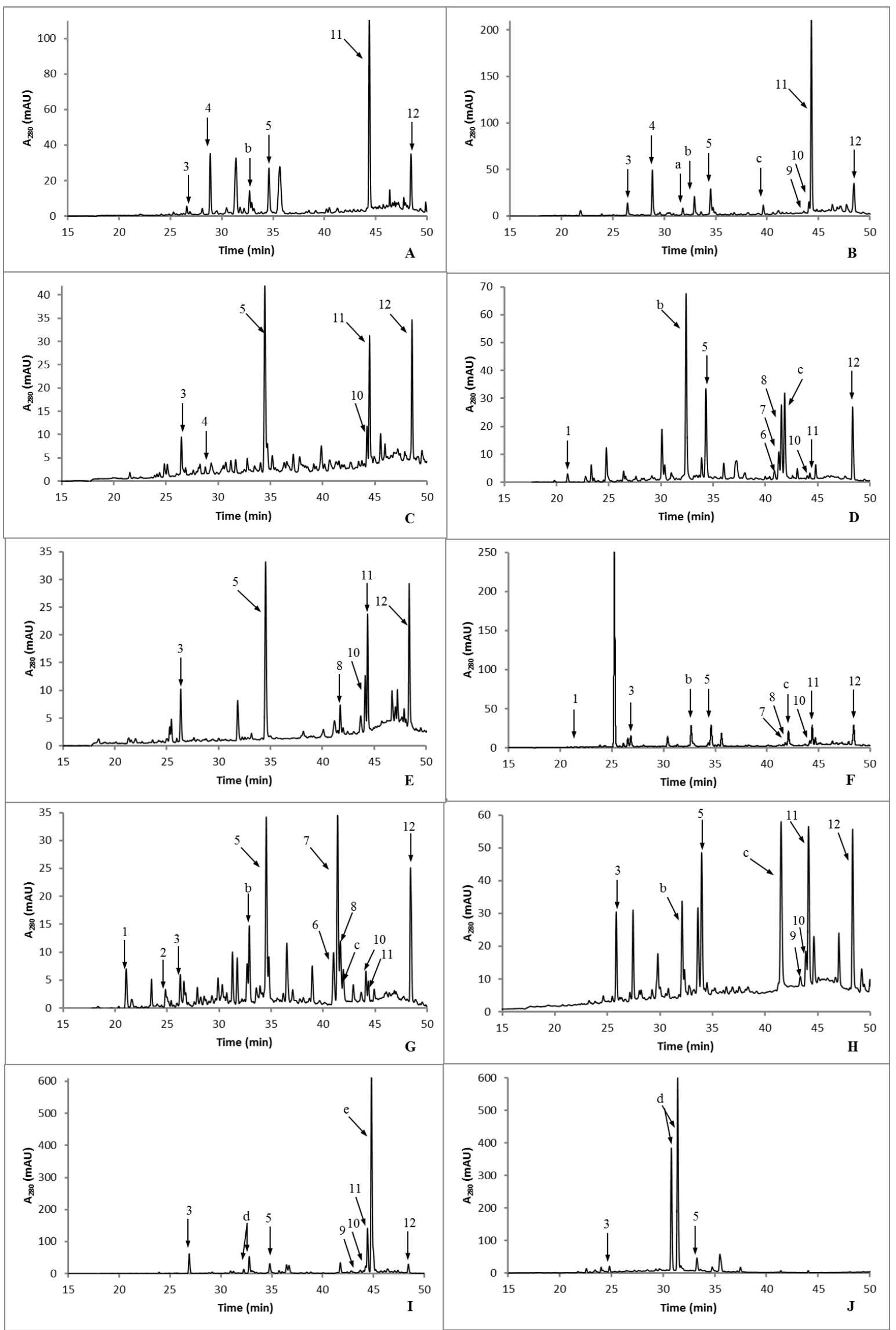


Figure A.2

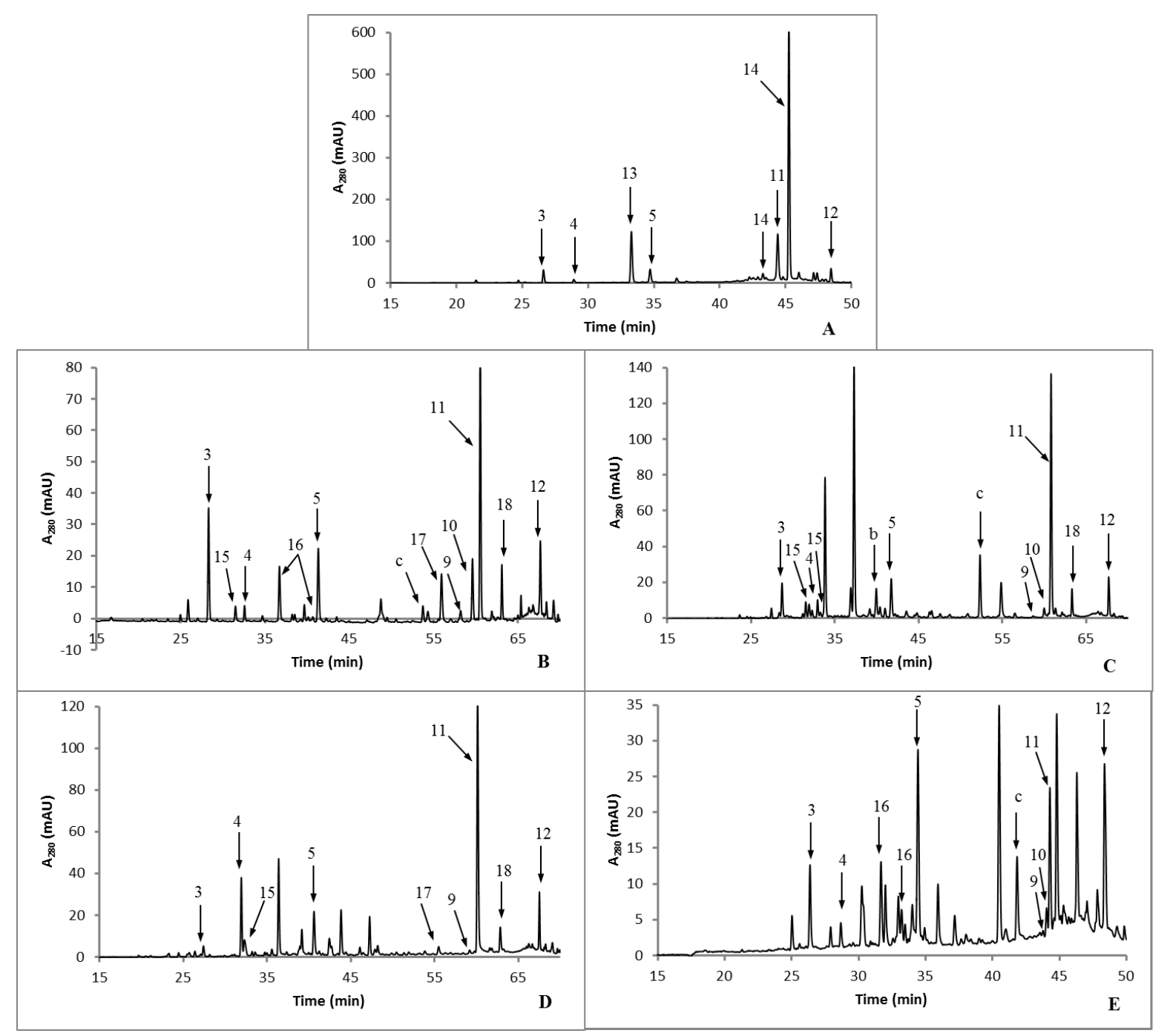

